\title{
POSTMORTEM INVESTIGATIONS ON WINTER STRANDED SPERM WHALES FROM THE COASTS OF BELGIUM AND THE NETHERLANDS
}

\author{
Thierry Jauniaux,' Laurence Brosens,' Eric Jacquinet,' Denis Lambrigts,' Marjan Addink, ${ }^{2}$ \\ Chris Smeenk, ${ }^{2}$ and Freddy Coignoul' \\ 1 Department of Pathology, Veterinary College, University of Liege, Sart Tilman B43, 4000 Liege, Belgium \\ 2 National Museum of Natural History, P.O. Box 9517, 2300 RA Leiden, The Netherlands
}

ABSTRACT: During winter 1994-95, four and three sperm whales (Physeter macrocephalus) were stranded along the Belgian and the Dutch coasts, respectively. Necropsies and tissue samplings were collected $24 \mathrm{hrs}$ post mortem. Lesions on several whales included round and linear skin scars, ventral skin abrasions, acute skin ulcers, acute ulcerative stomatitides, acute to chronic external otitides, and passive visceral congestion. In addition, these sperm whales appeared to be debilitated with severe weight deficit, had blubber thickness reduction, the absence of abdominal fat, and the intestinal tracts were almost empty. Three categories of lesions and their possible relation with the stranding were evaluated. Cutaneous scars observed on the seven whales appeared to have no relation with the stranding. The poor body condition and acute integument ulcerative lesions were present before the stranding. Ventral skin abrasions and visceral passive congestion were caused by the strandings. Absence of food in the alimentary tracts, evidence of weight loss and blubber thickness reduction were compatible with an extended presence of the sperm whales in the North Sea, where adequate food is not available. This might lead to progressive weakness, predisposing the animals to secondary pathogens such as viral diseases. Finally, the coastal configuration of the southern North Sea makes it a trap for sperm whales which have entered the area during their wanderings.

Key words: Sperm whale, Physeter macrocephalus, pathology, mass strandings, ulcerative integument lesions, poor body condition.

\section{INTRODUCTION}

Mass strandings of whales and dolphins have always intrigued people and must have occurred from the time cetaceans have been present in the oceans (Walsh et al., 1990). Such stranding has been defined as an event where two or more animals run ashore alive at roughly the same place and time (Geraci and Lounsbury, 1993). Many theories have attempted to explain that phenomenon. In most cases, it cannot be attributed to a single cause, but it is the result of a complex interaction of physical and biological factors such as ocean currents, tides and coastal configuration, the animals' migratory and social behavior, food availability, echolocation or orientation failure, and long-standing diseases which have debilitating effects (Cordes, 1982; Walsh et al., 1990; Geraci and Lounsbury, 1993).

Several mass strandings of sperm whales (Physeter macrocephalus), the largest of toothed whales (Odontoceti), occurred in the North Sea during the winter 1994-95 (Fig. 1). Sperm whales are highly pelagic animals and are normally found in deep oceanic waters. Their main food is mesopelagic squid, which is caught at depths of $\geq 1,000 \mathrm{~m}$ (Rice, 1989). Sperm whales live in groups which often show a strong social cohesion. Females and calves remain on the breeding grounds in warm to warmtemperate waters. Males leave the female herds when they reach puberty, and adult males perform long-distance migrations far into higher latitudes (Best, 1979; Rice, 1989). In the northeastern Atlantic Ocean, sperm whale bulls are often observed west of the British Isles and off the coast of Norway (Evans, 1991; Berrow et al., 1993). They avoid shallow waters and do not normally enter the North Sea, where physical and ecological conditions are totally unsuitable (Evans, 1991; Smeenk and Addink, 1993). Most sperm whale strandings in Europe are of single animals and usually occur on the Atlantic coast (Ber- 


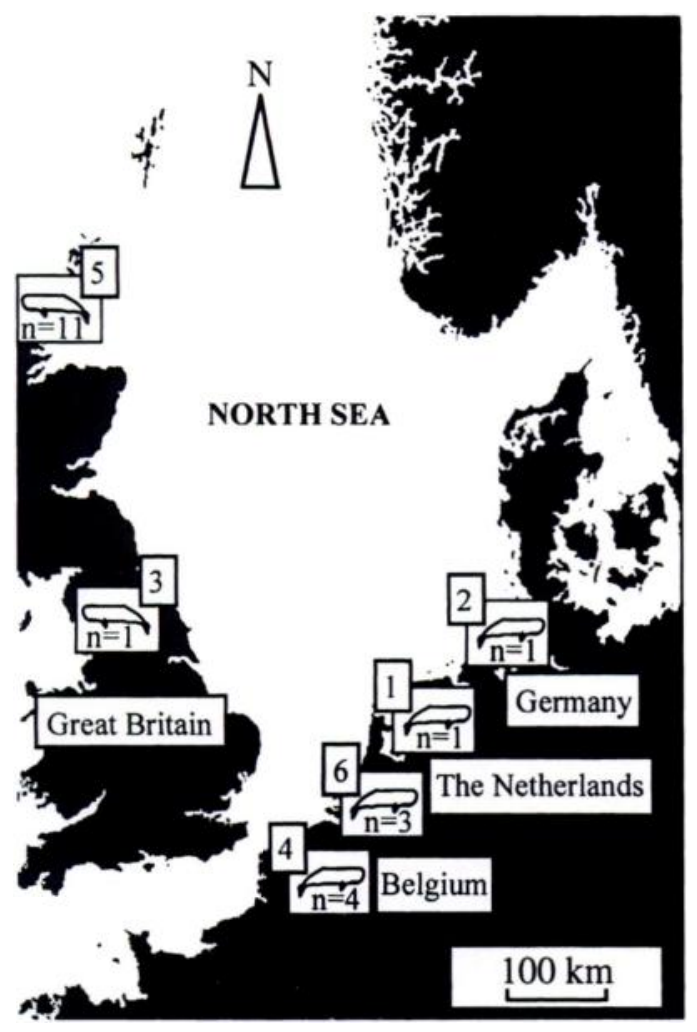

FIGURE 1. Sperm whale strandings recorded in the North Sea during the winter 1994-9.5 including (1) Terschelling on 3 November 1994, (2) Baltrum on 5 November 1994, (3) Whitby on 10 November 1994 , (4) Koksijde and Nieuwpoort on 18 November 1994. (5) Orkney on 9 December 1994, and (6) Scheveningen on 12 January 1995; ( $n=$ number of animals).

row et al., 1993; Camphuysen, 1995). However, mass strandings do occur and the great majority of those have been reported from the southern North Sea. This area is well outside the species' normal range and its coastline is characterized by intricate systems of sandbanks, mudflats, sandy islands and estuaries (Smeenk and Addink, 1993).

Few reports on pathology of sperm whales are available and these pertain to animals killed in commercial whaling operations (Cockrill, 1960a, 1960b; Uys and Best, 1966; Lambertsen et al., 1987; Lambertsen and Kohn, 1987). Data on pathology of sperm whales from mass stranding are virtually absent. Obviously, handling such animals on the beach and carrying out an adequate necropsy are extremely difficult, and require well coordinated teams including veterinary pathologists, and heavy equipment. In addition, necropsies should be done on fresh carcasses, since postmortem decay soon affects the quality of tissues and pathological findings. Nevertheless, accurate descriptions of lesions as well as attempts to determine their origin are prerequisites to evaluate the causes of death and the background to the stranding.

This paper describes postmortem observations on seven sperm whales stranded along the Belgian and Dutch coasts during the winter 1994-95. The possible causes of those strandings are discussed in the light of our post-mortem findings, findings of other strandings in the North Sea, and current knowledge on biology of sperm whales.

\section{MATERIALS AND METHODS}

On 18 November 1994, three fresh beached sperm whales were discovered dead at Koksijde $\left(51^{\circ} 08^{\prime} \mathrm{N}, 02^{\circ} 39^{\prime} \mathrm{E}\right)$, Belgium. A fourth sperm whale, probably from the same group, was found dead in shallow waters near the beach at Nieuwpoort $\left(51^{\circ} 09^{\prime} \mathrm{N}, 02^{\circ} 43^{\prime} \mathrm{E}\right), 10 \mathrm{~km}$ east from the first stranding area. It was dragged ashore later the same day. On 12 January 1995 , three sperm whales were found alive on the beach of Scheveningen $\left(52^{\circ} 05^{\prime} \mathrm{N}, 04^{\circ} 15^{\prime} \mathrm{E}\right)$, the Netherlands. They died $4 \mathrm{hr}$ after their discovery.

With the exception of the animal stranded in Nieuwpoort which was severely decayed, all whales were necropsied and sampled about 24 $\mathrm{hr}$ after death. A standardized procedure derived from the protocol for necropsy on small cetaceans (Kuiken and García Hartmann, 1991) was used on each carcass. Body measurements were taken and blubber thickness was measured at the caudal insertion of the dorsal fin. Samples of various organs and lesions were collected for histopathological examination and fixed in $10 \%$ buffered formalin. They were embedded in paraffin and $5 \mu \mathrm{m}$ sections were stained with hematoxylin and eosin (H\&E) stain. Sections of skin and oral mucosa were stained with Feulgen stain for evidence of nucleic acid (Bancroft and Cook, 1996) and sections of ear canal were stained with periodic acid Schiff (PAS) for fungi (Cook, 1996). Selected sections were stained by an immunope- 
TABLE 1. Body measurements, age and weight of sperm whales stranded on the Belgian and Dutch coasts during the winter 1994-95.

\begin{tabular}{|c|c|c|c|}
\hline $\begin{array}{l}\text { Loxation and } \\
\text { identification }\end{array}$ & $\begin{array}{l}\text { Le'ngth } \\
\text { (m) }\end{array}$ & $\begin{array}{c}\text { Blubber } \\
(\mathrm{mm})\end{array}$ & $\begin{array}{c}\text { Age } \\
\text { (Dentinal } \\
\text { GLG } \\
\text { count)a }\end{array}$ \\
\hline \multicolumn{4}{|l|}{ Koksijde } \\
\hline Sperm whale 1 & 15.4 & 160 & $24^{\mathrm{b}}$ \\
\hline Sperm whale 2 & 14.9 & 160 & $22^{c}$ \\
\hline Sperm whale 3 & 14.4 & 150 & 28 \\
\hline \multicolumn{4}{|l|}{ Nieuwpoort } \\
\hline Sperm whale 4 & 18.2 & 150 & $>29$ \\
\hline \multicolumn{4}{|l|}{ Scheveningen } \\
\hline Sperm whale A & 15.2 & 110 & $>31$ \\
\hline Sperm whale B & 15.4 & 120 & $>26$ \\
\hline Sperm whale $C$ & 15.3 & 106 & $>31$ \\
\hline
\end{tabular}

a GLG = growth layer groups.

b Worn tooth crown.

"Very worn tooth crown.

roxidase technique for morbillivirus antigen detection using monoclonal antibody clone PDV 1.3 (Kennedy et al., 1991; Trudgett et al., 1991; Domingo et al., 1992). Lung sections from morbillivirus-infected dolphins were used as positive controls (Domingo et al., 1992). For electron microscopy, selected formalin-fixed tissues were transferred to $2.5 \%$ glutaraldehyde in phosphate buffer, rinsed, post-fixed with osmium tetroxide, and embedded in epoxy resin (EM 812, Electron Microscopy Sciences, Fort Washington, Pennsylvania, USA).

Intestinal contents were aseptically collected for bacteriological examination by culture on Columbia Blood agar with $5 \%$ sheep blood (Becton Dickinson Benelux S.A., Erembodegem, Belgium) and on selective medium for Enterobacteriaceae (Gassner agar, Merck,
Merck-Belgolabo S.A., Overijse, Belgium) and incubated overnight in aerobic and anaerobic conditions. In addition, blowhole and external ear duct swabs were sampled on two and one sperm whales from Belgium and the Netherlands, respectively. For parasitology, intestinal contents were sampled, parasites were collected and preserved in $70 \%$ ethanol prior to identification.

The sperm whales stranded along coast of Belgium were weighed at the process plant at the time of carcass disposal. Weight was corrected for body fluid loss during necropsy and transport (Lockyer, 1991) and a predictive formula of normal weight was used from measured length (Lockyer, 1991). Teeth were collected and forwarded to the Sea Mammal Research Unit (Cambridge, United Kingdom; C. Lockyer) for age determination by counting the growth layer groups.

\section{RESULTS}

All seven animals examined were adult males, about $15 \mathrm{~m}$ long; the one found near Nieuwpoort was $18 \mathrm{~m}$ long (Table 1). Blubber thickness was about $16 \mathrm{~cm}$ in sperm whales from Belgium, $\leq 12 \mathrm{~cm}$ in those from the Netherlands. Age determination (Table 1) revealed that the largest whale from Nieuwpoort was >29-yrold. Some teeth were so worn that the age could not be precisely determined. Body mass at necropsy, corrected and estimated weights are presented in Table 2. The whale stranded at Nieuwpoort weighed more than $34,000 \mathrm{~kg}$. Lesions observed on each animal, listed in Table 3 , are described below.

Several parallel linear white scars 15 to

TABLE 2. Length, weight (observed and corrected) and predicted normal weight of sperm whales stranded on the Belgian coast, 1994.

\begin{tabular}{|c|c|c|c|c|}
\hline $\begin{array}{l}\text { Lexcation and } \\
\text { identification }\end{array}$ & $\begin{array}{c}\text { Length } \\
\text { (iii) }\end{array}$ & $\begin{array}{l}\text { Weight:" } \\
\text { (kg) }\end{array}$ & $\begin{array}{l}\text { Corrected } \\
\text { weight }^{b} \\
(\mathrm{~kg})\end{array}$ & $\begin{array}{l}\text { Estimated } \\
\text { weightc }^{c} \\
(\mathrm{~kg})\end{array}$ \\
\hline \multicolumn{5}{|l|}{ Koksijde } \\
\hline Sperm whales $1+2$ & 15.4 and 14.9 & $60,870^{d}$ & $70,000^{d}$ & $74,800^{d}$ \\
\hline Sperm whale 3 & 14.4 & 19,245 & 21,940 & 32,500 \\
\hline \multicolumn{5}{|l|}{ Nieuwpoort } \\
\hline Sperm whale 4 & 18.2 & 34,205 & 38,994 & 61,800 \\
\hline
\end{tabular}

a Weight at the process plant at the time of carcass disposal, after partial dissection on the beach.

b Correction factor 1.14 was used to compensate for loss of body fluids during dissection and transport (Lockyer, 1991).

c Predictive formula of normal weight was used from measured length as $\mathrm{W}=0.0218 \times \mathrm{L}^{2.74}$ (Lockver, 1991).

"Combined weight. 
TABIE 3. Pathological findings obsened in sperm whales stranded on the Belgian and Dutch coasts during the winter 1994-95.

\begin{tabular}{|c|c|c|c|c|c|c|c|c|c|}
\hline $\begin{array}{l}\text { Iexation and } \\
\text { identification }\end{array}$ & $\begin{array}{l}\text { Chronic } \\
\text { skin } \\
\text { lesions }\end{array}$ & $\begin{array}{l}\text { Ventral } \\
\text { abrat- } \\
\text { sions }\end{array}$ & $\begin{array}{l}\text { Acute } \\
\text { skin } \\
\text { ulcers }\end{array}$ & $\begin{array}{l}\text { Acute } \\
\text { ulcerat- } \\
\text { tive } \\
\text { stomat- } \\
\text { titis }\end{array}$ & $\begin{array}{c}\text { External } \\
\text { otitis }\end{array}$ & $\begin{array}{l}\text { Blubber } \\
\text { of intes- } \\
\text { tinal } \\
\text { nodules }\end{array}$ & $\begin{array}{l}\text { Visceral } \\
\text { conges- } \\
\text { tion }\end{array}$ & $\begin{array}{l}\text { Ciastric } \\
\text { nemal- } \\
\text { todes }\end{array}$ & $\begin{array}{c}\text { Acute } \\
\text { ulcera- } \\
\text { tive } \\
\text { tonsil- } \\
\text { litis }\end{array}$ \\
\hline \multicolumn{10}{|l|}{ Koksijde } \\
\hline Sperm whale I & $+a$ & + & $-b$ & - & $x$ & + & + & - & $?$ \\
\hline Sperm whale 2 & + & + & - & + & $?$ & + & + & + & $?$ \\
\hline Sperm whale 3 & + & + & + & + & + & - & + & + & $?$ \\
\hline \multicolumn{10}{|l|}{ Nieuwpoort } \\
\hline Sperm whale 4 & + & - & - & - & $?$ & $?$ & $?$ & $?$ & $?$ \\
\hline \multicolumn{10}{|l|}{ Scheveningen } \\
\hline Sperm whale A & + & + & + & + & + & + & + & + & $?$ \\
\hline Sperm whale B & + & + & - & + & + & + & + & + & $?$ \\
\hline Sperm whale C: & + & + & - & + & + & + & + & + & + \\
\hline
\end{tabular}

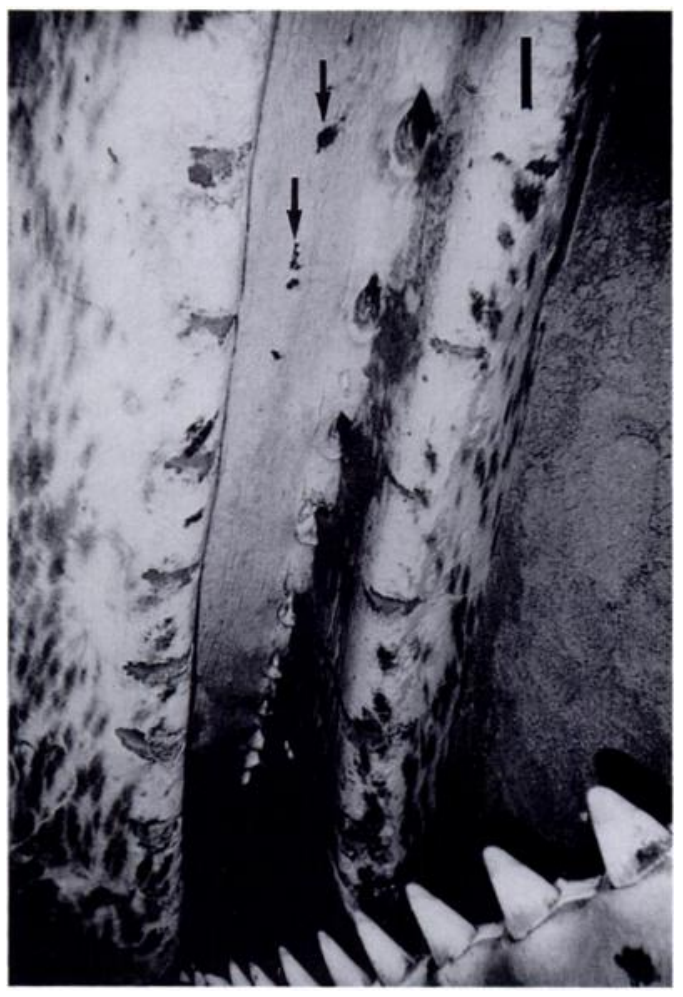

FIGLiRE 2. Mouth of sperm whale from stranding on Belgian coast showing acute ulcers (arrow) on the midline of the hard palate, and segmental lacerations on the lips which are postmortem artifacts. (Bar = $10 \mathrm{~cm})$.
$25 \mathrm{~cm}$ in length and $1 \mathrm{~cm}$ in width and several starry white scars were observed on the heads of all seven animals. Slightly hemorrhagic skin ulcerations also were present on the ventral lower abdomen, on the longitudinal midline and laterally, around the genital area and on the tail of the animals from Koksijde and Scheveningen.

Unusual lesions on two of the sperm whales from Belgium were three to four acute ulcers on the midline of the hard palate (Fig. 2). Those lesions were elongated, 2 to $10 \mathrm{~cm}$ in length and $4 \mathrm{~cm}$ in width, with irregular edges. They were red-brown, with hemorrhagic fluid oozing from the lesions, and some ulcers were covered by fibrin. Similar lesions, $\leq 30 \mathrm{~cm}$ long, were observed on the three animals from the Netherlands (Fig. 3). Round to oval ulcers, 4 to $5 \mathrm{~cm}$ in diameter, with raised, irregular, whitish edges, were present on the dorsal and lateral sides of the tail stock of one sperm whale from Belgium. Round and white erosions of 2 to 3 $\mathrm{cm}$ in diameter with slightly raised and rough edges were observed on the head of one whale from the Netherlands (Fig. 4). Lesions had slightly depressed centers and 


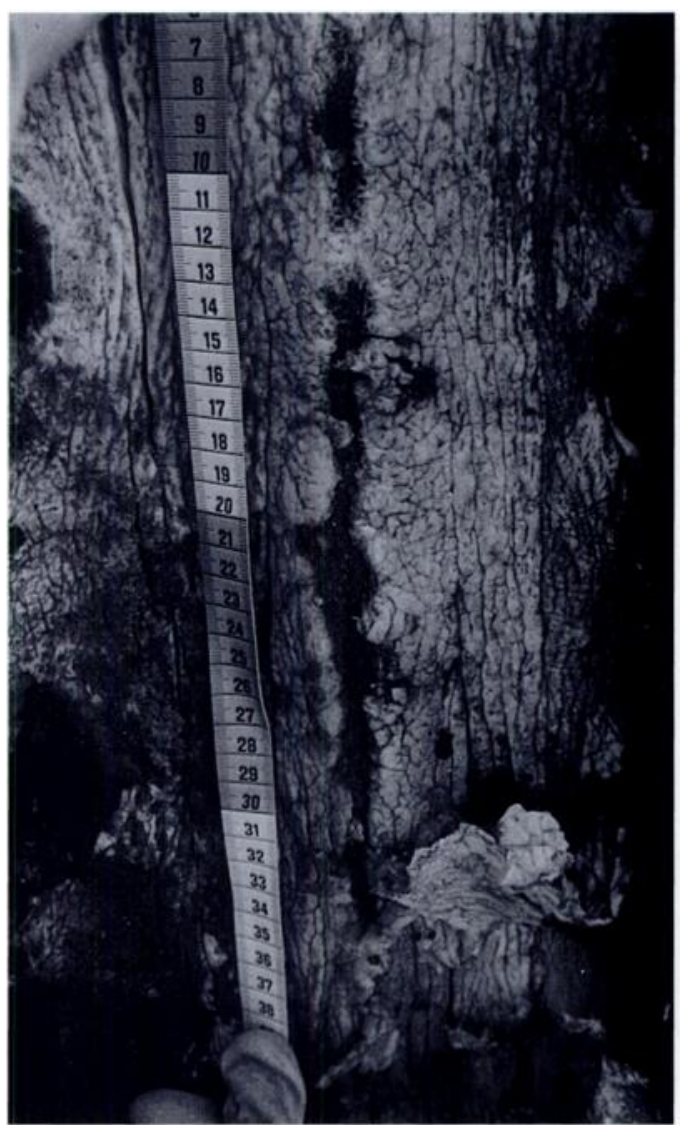

FIGURE 3. Mouth of sperm whale stranded on Dutch coast with large acute ulcers $(30 \mathrm{~cm}$ long) on the midline of the hard palate.

were limited by a dark gray outline, $2 \mathrm{~cm}$ wide. Of one and three sperm whales from the Belgian and Dutch coast, respectively, external ear was examined. The ear duct was round to oval, 9 to $11 \mathrm{~cm}$ long, about $15 \mathrm{~mm}$ in diameter, and contained solid debris resembling skin fragments. Transverse sections of the wall indicated an irregular thickness, 2 to $6 \mathrm{~mm}$, with a red margin in the deeper layer. The duct was covered by corrugated and folded white epithelium. On two animals from the Dutch coast, acute ulcers 1 to $4 \mathrm{~cm}$ long were located in the outer third of the external ear duct (Fig. 5).

A longitudinal skin slit, $34 \mathrm{~cm}$ long, with slightly raised edges forming labia, was found on the upper left side of the rostrum, left of the blowhole, $35 \mathrm{~cm}$ behind

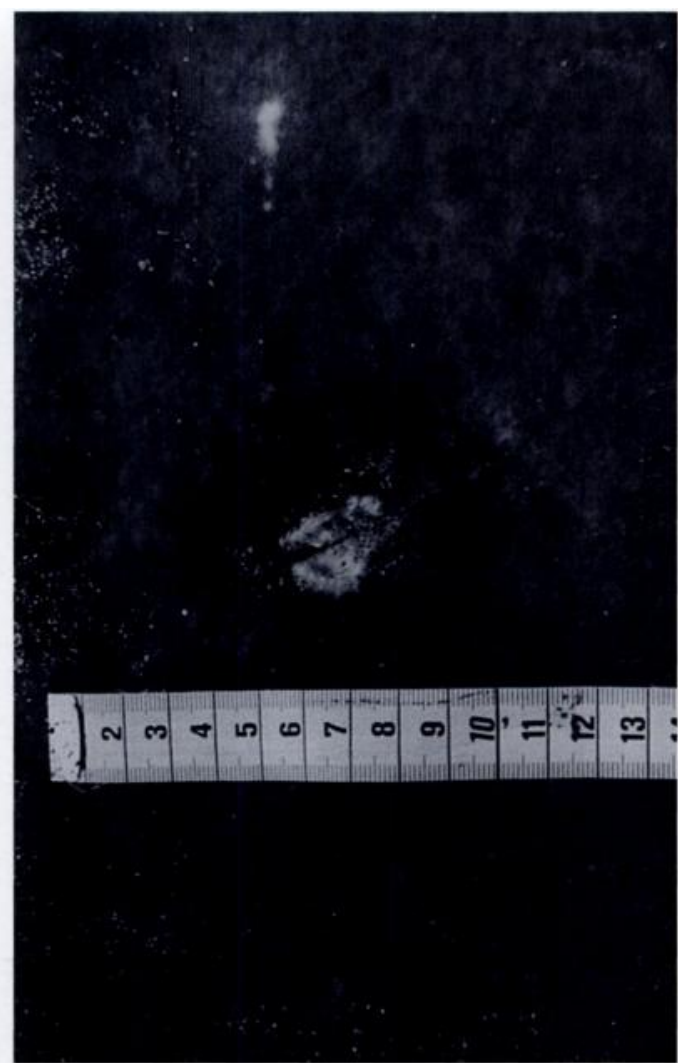

Figure 4. Head of sperm whale stranded on coast of the Netherlands showing slight skin erosion with raised, rough edges, and dark gray outline.

the cranial edge of the head of one whale from the Belgian coast. The bottom of the fold communicated with a blind oval duct, $30 \mathrm{~cm}$ deep, covered with skin.

White nodules, $1 \mathrm{~cm}$ in diameter with a 2 to $3 \mathrm{~mm}$ thick wall and yellowish, translucent centers, were found in the blubber of four whales.

Observations of bodly cavities were similar in all animals, principally a generalized visceral passive congestion. Muscle layers of the abdominal wall were evenly dark red to black. Livers were entirely dark red, almost black, with rounded edges. Renal cortices were dark red, medullae were brick-red. The omentum and the serosal surface of the intestine were severely congested, with prominent blood vessels, most segments being evenly brick- to dark red. Gas bubbles were present on the mucosal 


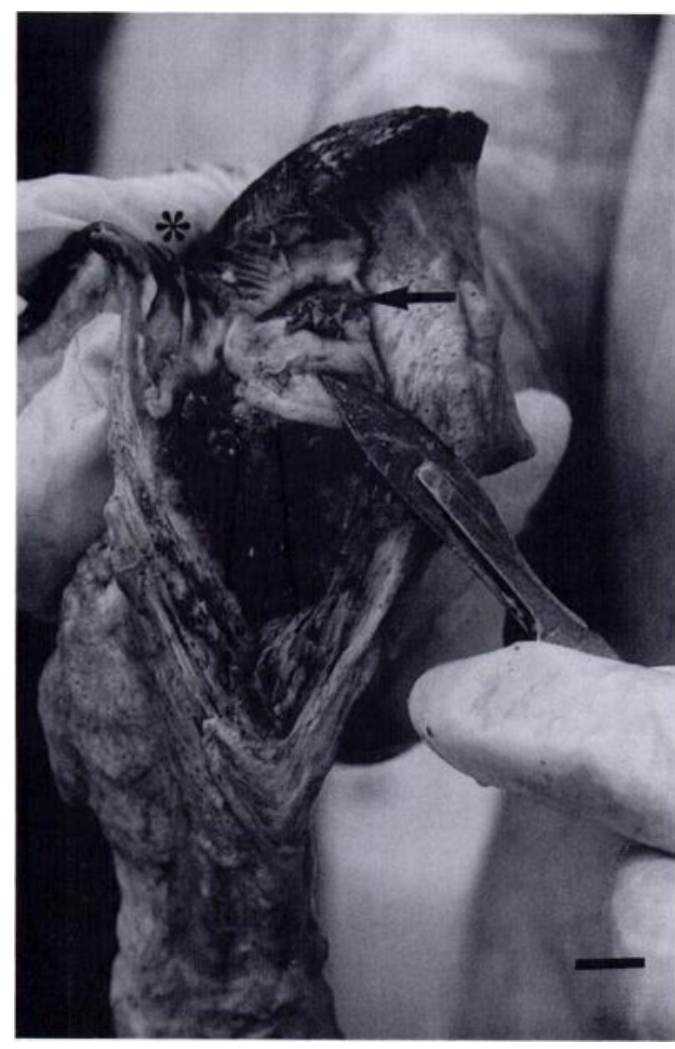

Figure 5. Sperm whale from stranding on Dutch coast showing dissected ear duct demonstrating acute external otitis with large ulcerative areas (arrow) and the external ear duct meatus $(*)$. (Bar $=1 \mathrm{~cm})$.

surface, indicating early putrefaction. $\mathrm{Nu}$ merous nematodes (Anisakis sp.) were observed in the gastric lumen of five animals (Table 3). In two sperm whales, many 2 $\mathrm{cm}$ diameter flat hematomas were spread on various segments of the intestinal serosa, bleeding upon incision. In one whale, many white $1 \mathrm{~cm}$ diameter nodules were adherent to the serosal surface of various intestinal segments. Gastric and intestinal lumens were almost empty except for few cephalopod beaks between the gastric folds of the sperm whales from Belgium. There was no abdominal fat. Lungs were evenly pinkish red without foam or blood on the cut surface in one sperm whale from Belgium while, in whales from the Netherlands, they were dark red, with bloody fluid oozing from tissue at sectioning. The tongue base was observed in one case (Table 3). In the tonsillar area, near the base of the tongue, the oral mucosa had a purplish-red $2 \mathrm{~cm}$ diameter area. Upon sectioning, the oral epithelium invaginated to form a blind duct, $3 \mathrm{~cm}$ deep and $1 \mathrm{~cm}$ in diameter with congestive wall and several dark red 8 to $10 \mathrm{~mm}$ nodules were observed in the wall. At the level of the tonsillar duct opening, three round acute $1 \mathrm{~cm}$ diameter ulcers were observed.

Microscopically, ulcerative lesions in the mouth were diagnosed as acute to subacute ulcerative stomatitis. Ulcers were deep, exposing dermal connective tissue with hemorrhage, necrosis and edema in the outermost layer and a severe lichenoid infiltrate of neutrophils and lymphocytes was observed. Ulcer edges were sharply defined. In epidermal layers around ulcers, spongiosis and ballooning degeneration were observed and formed intraepidermal microvesicles. Some were larger and formed small pustules. In some ballooned cells, weakly Feulgen positive eosinophilic, cytoplasmic inclusion bodies were present. Nuclei were not visible or reduced to small, crescent shape, dense, basophilic remnants. At some distance from the ulcer, similar changes were present, limited to superficial cell layers with a mild plasma cell infiltration at the dermoepidermal junction. Strata germinativum and spinosum formed deep rete ridges in dermis (epidermal hyperplasia) with many mitoses in the basal layer. Acute to subacute perivascular dermatitis was observed around superficial capillaries. The skin ulceration observed on the tail stock of one whale from Belgium was diagnosed as subacute ulcerative dermatitis. A skin erosion on the head of one sperm whale from the Dutch coast was characterized by marked intracellular edema and nucleus displacement of stratum intermedium cells, with some areas of mild acute dermatitis. Ballooning degeneration and eosinophilic intracytoplasmic inclusion bodies also were present. Ear lesions were similar in both groups and were diagnosed as severe diffuse ulcerative subacute to 
chronic external otitis. Fungi were not detected with PAS stain. The tonsil lesion was diagnosed as an acute tonsillitis, characterized by a massive, diffuse infiltrate of neutrophils and pycnotic cells in tonsillar crypts.

Blubber and subserosal cyst were encapsulated unidentified cestode larvae. In the blubber, they were characterized by an outer cuticule and an inner matrix containing calcareous corpuscules and invaginated scolex, suggesting cysticercus like structure. Postmortem changes in other tissues were severe, precluding any valid microscopic evaluation. Sections of skin, hard palate, tonsil and ear duct were tested for morbillivirus and were all negative.

Skin and hard palate ulcers were examined with electron microscopy. Keratinocytes in basal layers were severely vacuolated, nuclei were large and pale. In more superficial layers, intracellular edema was prominent. In less modified cells, the cytoplasm was rich in polyribosomes. Viral particles were not observed.

Bacteriae isolated from intestinal contents were Escherichia coli, Enterobacter aerogenes, Clostridium perfringens, Proteus sp. and Bacillus sp.. From the blowhole, Escherichia coli was isolated. The external ear duct had Staphylococcus sp. and Clostridium perfringens.

\section{DISCUSSION}

Three groups of lesions were identified in the sperm whales stranded on the Belgian and Dutch coasts; these included (1) chronic scars, (2) integument ulcers and poor body condition, and (3) skin erosions with generalized passive congestion. In the first group were various chronic skin lesions. Round scars were probably impressions made by squid tentacles and longitudinal parallel scars on the head probably were the result of fights between males (Evans, 1993). Both types of lesions are normal findings in adult male sperm whales. The slit communicating with a blind duct observed on the head of one sperm whale from Belgium was consid- ered to be a vestigial blowhole. Rare cases of sperm whales with two distinct blowholes have been reported (Milinkovitch, 1995). These findings had no relation to the stranding.

The second group of lesions included various integument ulcerations. Oral and skin ulcers were suggestive of a viral infection (Yager and Scott, 1993) and electron microscopy investigations revealed that cytoplasm was rich in polyribosomes indicating active protein synthesis. However, no viral particles were seen and a morbillivirus antigen was not demonstrated in tissues using immunoperoxidase. It is likely that postmortem autolysis can prevent detection of antigens and hamper the diagnosis of viral disease such as morbillivirus infection (Lipscomb et al., 1994b; Krafft et al., 1995). More sensitive techniques, such as the polymerase chain reaction (PCR) were not performed on the tissues, but would have been of some assistance. Ulcerative or erosive stomatitides have been described for beluga whales (Delphinapterus leucas) by De Guise et al. (1995), for distemper-infected Atlantic bottlenose dolphins (Tursiops truncatus) by Lipscomb et al. (1994a) and for distemper-infected striped dolphins (Stenella coeruleoalba) by Domingo et al. (1992, 1995) and Duignan et al. (1992). According to Domingo et al. (1992), these lesions were attributable to secondary opportunistic agents or to infections by calicivirus, herpesvirus or picornavirus. Tonsillitis occurs in various viral infectious diseases (Barker et al., 1993) and in distemper-infected dolphins, morbillivirus antigen has been demonstrated in tonsillar tissue (Domingo et al., 1992). In sperm whales, tonsillar tissue has been described as crypts, located at the base of the tongue (Uys and Best, 1966). Macroscopic and microscopic descriptions of skin erosions and ulcers (sperm whale tail stock from Belgian and one whale head from Dutch coast) are similar to those given for poxvirus and herpesvirus infections in wild cetaceans (Baker, 1992a; 1992b; Baker and Martin, 
1992), and for poxvirus infection in domestic animals (Yager and Scott, 1993; Cheville, 1994). Both viral infections occured in stressed cetaceans, or under poor environmental conditions (Geraci et al., 1979; Martineau et al., 1988).

Ulcerative subacute to chronic external otitis was observed in all the sperm whales we examined. Apparently, similar lesions in cetaceans have not been previously described. Pseudomonas sp. bacteria and $\mathrm{Ma}$ lassezia sp. yeasts are associated with ulcerative chronic otitis in domestic animals (Wilcock, 1993), but bacteria were not isolated and fungi were not seen in surface keratin or in ear canal debris of the stranded sperm whales. The potential extension of such lesions to the middle and inner ear has been reported for domestic animals. In those species, progression through the eighth cranial nerve is frequent and can lead to meningitis and encephalitis (Wilcock, 1993). In cetaceans, lesions in the eighth cranial nerve due to parasitic infection have been suspected to lead to echolocative and vestibular dysfunctions leading to mass strandings (Morimitsu et al., 1986,1987 ). Unfortunately, we could not investigate the possible extension of the lesions in the skull of the sperm whales.

In addition to integument lesions, the stranded sperm whales were in poor body condition, as indicated by their low weight, absence of abdominal fat and reduced blubber layers compared with data from healthy animals caught during commercial whaling operations (Lockyer, 1991). In particular, two whales had a severe weight deficit in comparison to their predicted weight. Blubber thickness in the sperm whales from the Dutch coast was lower than values reported by Lockyer (1991) for the same body region (between 15 and 20 $\mathrm{cm})$. Weight loss and blubber thickness reduction suggested a poor nutritional state and a chronic debilitating process. Poor body condition and absence of food in the alimentary tract are frequent findings in stranded cetaceans (Cordes, 1982; Domingo et al., 1992).
This second group of lesions including integument ulcers and poor body condition were present before the strandings and may have played a role in the stranding accidents. It is probable that viral infections, possibly responsible for ulcerative digestive lesions, accelerated the debilitation process. The real importance of those lesions in regard to the strandings is unknown.

The third group of lesions included slightly hemorrhagic skin erosions on the lower abdomen and on the flukes. They were mechanical abrasions due to the rubbing of the animals on the sand during agony. They are frequently reported for stranded whales (Geraci and Lounsbury, 1993; Needham, 1993). Because these lesions were perimortem, it is likely that the sperm whales on the Belgian coast were stranded alive. Similar erosions were not observed on the animal that died at sea.

Visceral passive congestion and disseminated hemorrhages of the intestinal serosa suggested an acute circulatory disturbance as the cause of death, likely shock following cardiovascular failure (Cotran et al., 1994). The shock process is one of the more frequent consequences of marine mammals stranding (Geraci and Lounsbury, 1993; Needham, 1993). Thus, this third group of lesions was probably the direct result of the stranding and indicated the most likely cause of death. The bacteriological and parasitological findings were insignificant.

Finally, our observations on the lesions of stranded whales coupled with an understanding of sperm whale behavior, and of the physical and ecological conditions of the coastal areas involved enabled us to venture an hypothesis on the cause of mass strandings of sperm whales in the southern North Sea (Fig. 6). The animals stranded on the Belgian and Dutch coasts apparently had not fed for a considerable time (empty intestinal tracts, reduction of weight and blubber thickness, absence of abdominal fat). Weight loss and blubber thickness reduction were chronic process- 


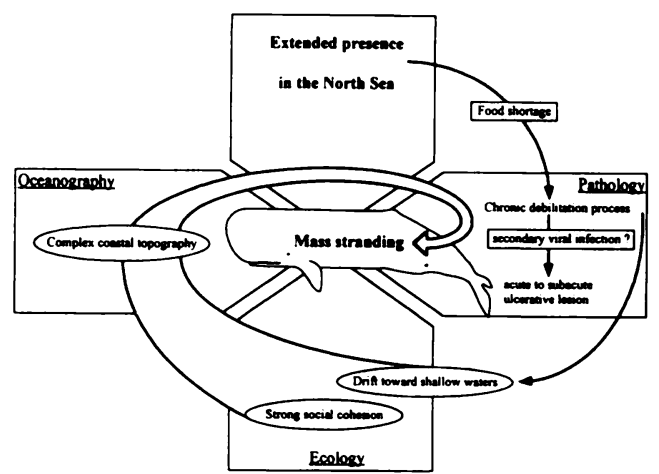

FIGCRE 6. Schematic representation of the hypothesis for the mass strandings of sperm whales on the Belgian and Dutch coasts during winter 1994-95.

es, which had advanced further in the whales stranded on the Dutch coast 2 mo after those on the Belgian coast. All other lesions were acute to subacute. Possibly, chronic debilitation predisposed these whales to secondary infections.

Sperm whales probably enter the North Sea on their way south from North Atlantic waters. This is consistent with the known distribution area of sperm whale bulls off the coast of Scotland and Norway, and their predominantly southward migration during fall or early winter. It is not known what may cause some sperm whales to take a route too far to the east, which leads them straight into the North Sea. That they may do so, is corroborated by the stomach contents of the two sperm whales stranded November 1994 in the Dutch and German Wadden Sea (Fig. 1). These consisted of large quantities of squid beaks of species occurring in North Atlantic waters, north of the North Sea (Lick et al., 1996). Although the northern North Sea is generally $>100 \mathrm{~m}$ deep, it becomes progressively shallower further south. The southern part is funnel-shaped and $<40 \mathrm{~m}$ deep. The configuration of its coastlines is complex, with numerous sandbanks, estuaries and treacherous differences in tides. This area must be totally unfamiliar to deep-diving oceanic animals like sperm whales. Debilitated animals which have roamed through the North Sea for some time could be particularly prone to confusion and might eventually become grounded or trapped by a falling tide. Social cohesion would keep the animals together, and a mass stranding could result. Because of its geography and topography, the North Sea is regarded as a potential trap for sperm whales, and weakened animals have very little chance to escape from this "cul-de-sac."

\section{ACKNOWLEDGMENTS}

The authors acknowledge $\mathrm{T}$. Jacques, J. Tavernier, the Ceto-Club students and all the people who helped us on the beaches of Koksijde, Nieuwpoort and Scheveningen. The authors thank M. Domingo for providing tissues of morbillivirus-infected dolphin, A. Trudgett for providing the monoclonal antibody to the phocine distemper virus, C. Lockyer for age determination and M. Sarlet, R. Nef, G. Charlier and J-François Bradfer for technical assistance. Thanks also are due to M. García Hartmann for useful comments on the manuscript. This work was funded by the Impulse Programme in Marine Sciences, supported by the Belgian State - Prime Minister's Services, Office for Scientific, Technical and Cultural Affairs (Contract MS/12/033) and by the European Community (NORSPA 90-1/B/002).

\section{LITERATURE CITED}

BAKER, J. R. 1992a. Skin disease in wild cetaceans from British waters. Aquatic Mammals 18: 2732.

1992b. Causes of mortality and parasites and incidental lesions in dolphins and whales from British waters. Veterinary Record 130: 569 572 .

- AND A. R. MARTIN. 1992. Causes of mortality and parasites and incidental lesions in harbour porpoises (Phocoena phocoena) from British waters. Veterinary Record 130: 554-558.

Bancroft J. D., AND H. C. COOK. 1996. Proteins and nucleic acids. In Theory and practice of histological techniques, J. 1). Bancroft and A. Stevens (eds.). Churchill Livingstone, New York, New York, pp. 139-150.

Barker, I. K., A. A. VaN Dreliel, a.d J. Palmer. 1993. The alimentary system. In Pathology of domestic animals, Vol. 2, K. V. F. Jubb, P. C. Kennedy, and N. Palmer (eds.). Academic Press, San Diego, California, pp. 1-318.

BERROW, S. D., P. G. H. EvaNS, AND M. C. SHELDRICK. 1993. An analysis of sperm whale Physter macrocephalus $\mathrm{L}$. stranding and sighting records 
from Britain and Ireland. Journal of Zoology 230: 333-337.

BEST, P. B. 1979. Social organization in sperm whales, Physeter macrocephalus. In Behavior of marine animals. Current perspectives in research. Vol. 3: Cetaceans, M. E. Winn and B. L. Olla (eds.). Plenum Press, New York, New York, pp. 227-289.

CAMPhUYSEN, C. J. 1995. Strandings of Sperm Whales Physeter macrocephalus in the NE Atlantic region: a review. Report to the Task Force of the Marine Mammal Action Plan. Camphuysen Seabird Research Consultancy Report 19961, Oosterend, Texel, the Netherlands, $48 \mathrm{pp}$.

Cheville, N. F. 1994. Ultrastructural pathology: an introduction to interpretation. Iowa State University Press, Ames, Iowa, pp. 946.

Cockrill, W. R. 1960a. Pathology of the cetacea a veterinary study on whales-Part 2. British Veterinary Journal 116: 179-189.

1960b. Pathology of the cetacea a veterinary study on whales-Part 1. British Veterinary Journal 116: 133-144.

CoOK H. C. 1996. Carbohydrates. In Theory and practice of histological techniques, J. D. Bancroft and A. Stevens (eds.). Churchill Livingstone, New York, New York, pp. 173-211.

CORDES, D. O. 1982. The causes of whales strandings. New Zealand Veterinary Journal 30: 21-24.

COTRaN, S. R., V. KUMAR, AND S. L. RobBins. 1994 Hemodynamic disorders, thrombosis, and shock. In Pathologic basis of diseases, R. S. Cotran, V. Kumar, and S. L. Robbins (eds.). W. B. Saunders company, Philadelphia, Pennsylvania, pp. 93121.

De Guise, S., A. LaGace, P. Beland, C. Girard, AND R. Higgins. 1995. Non-neoplastic lesions in beluga whales (Delphinapterus leucas) and other marine mammals from the St Lawrence estuary: Journal of Comparative Pathology 112 $257-271$.

Domingo, M., J. Visa, M. Pumarola, A. J. Marco, L. FERRER, R. RABANal, AND S. KENNEDY 1992. Pathologic and immunocytochemical studies of morbillivirus infection in striped dolphins (Stenella coeruleoalba). Veterinary Pathology 29: 1-10.

- M. Vilafranca, J. Visa, N. Prats, a. TRLDGETT, AND I. K. G. VISSER. 1995. Evidence for chronic morbillivirus infection in the Mediterranean striped dolphin (Stenella coeruleoalba). Veterinary Microbiology 44: 229-239.

Duignan, P., J. R. Geraci, J. A. Raga, ANd N. CaLZADA. 1992. Pathology of morbillivirus infection in striped dolphins (Stenella coeruleoalha) from Valencia and Murcia, Spain. Canadian Journal of Veterinary Research 56: 242-248.

Evass, P. G. H. 1991. Whales, dolphins and porpoises: order cetacea. In The handbook of British mammals, G. B. Corbet and S. Harris (eds.)
Blackwell Scientific Publications, Oxford, England, pp. 299-350.

. 1993. The natural history of whales and dolphins. Academic Press, London, England, 343 pp.

Geraci, J. R., B. D. Hicks, and D. J. St. Aubin. 1979. Dolphin pox: A skin disease of cetaceans. Canadian Journal of Comparative Medicine 43: 399-404.

-, AND V. J. Lounsbury. 1993. Marine mammals ashore a field guide for strandings. Texas A\&M Sea Grant publication, Galveston, Texas, $305 \mathrm{pp}$.

Kennedy, S., J. A. SMrth, P. F. Cush, M. MCAliskey, S. J. MCCullolgh, AND B. K. RiMA. 1991. Histopathological and immunocytochemical studies of distemper in harbour porpoises. Veterinary Pathology 28: 1-7.

Krafft, A., J. H. Lichy, T. P. Lipscomb, B. A. KlaunberG, S. Kennedy, and J. K. TaubenBERGER. 1995. Postmortem diagnosis of morbillivirus infection in bottlenose dolphins (Tursiops truncatus) in the Atlantic and (Gulf of Mexico epizootics by polymerase chain reactionbased assay. Journal of Wildlife Diseases 31: $410-415$.

Kuiken, T., and M. García Hartmann. 1991. Proceedings of the first European Cetacean Society workshop on Cetacean pathology: dissection techniques and tissue sampling. European Cetacean Society Newsletter 17: 1-39.

LAMBERTSEN, R. H., AND B. A. KOHN. 1987. Unusual multisystemic pathology in a sperm whale bull. Journal of Wildlife Diseases 23: 510-514.

- B. A. KoHN, J. P. Sundberg, aNd (. D). BUERGelt. 1987. Genital papillomatosis in sperm whale bulls. Journal of Wildlife Diseases 23: 361-367.

Lick, R, B. Bandomir-Krischak, M. Stede, J. WULF, AND H. BENKE. 1996. Case report on two large whales (Megaptera novaenglia and Physeter macrocephalus) in the (German part of the North Sea. In European Research on Cetaceans vol. 9, P.G.H. Evans, and H. Nice (eds.). European (Cetacean Society, Kiel, Germany, pp. 162-16.3.

LiPSCOMB, T. P., S. KENNEDY, D. MOFFETT, AND B. K. FORD. 1994a. Morbilliviral disease in an atlantic bottlenose dolphin (Tursiops truncatus) from the Gulf of Mexico. Journal of Wildlife Diseases 30: 572-576.

, F. Y. SChUlman, D. MOFFETT, AND S. KENNEDY. 1994b. Morbilliviral disease in Atlantic bottlenose dolphins (Tursiops truncatus) from the 1987-1988 epizootic. Journal of Wildlife Diseases 30: $567-571$.

LOCKYER, (.. 1991. Body composition of the sperm whales Physseter macrocephalus, with special reference to the possible functions of fat depots. Rit 
Fiskideilar Journal of the Marine Research Institute Reykjavik 12: 1-24.

Martineau, D., A. Lagace, P. Beland, R. Higgins, D. Armstrong, and L. R. Shugart. 1988. Pathology of stranded Beluga whales (Delphinapterus leucas) from the St Lawrence Estuary, Quebec, Canada. Journal of Comparative Pathology 98: 287-311.

MiLinKOVITCH, M. 1995. Molecular phylogeny of cetaceans prompts revision of morphological transformations. Tree 10: 328-334.

Morimitsu, T., T. NaGai, M. IDE, A. IShII, AND M. KOONO. 1986. Parasitic octavus neuropathy as a cause of mass stranding of Odontoceti. The Journal of Parasitology 72: 469-472.

- - - H. Kawano, A. NaichuU, M. KOONO, AND A. ISHII. 1987. Mass stranding of odontoceti caused by parasitogenic eighth cranial neuropathy. Journal of Wildlife Diseases 23: 586-590.

Needham, D. J. 1993. Cetacean strandings. In Zoo and wild animal medicine current therapy, M. E. Fowler (ed.). W. B. Saunders Company, Philadelphia, Pennsylvania, pp. 415-425.

RICE, D. W. 1989. Sperm whale Physeter macrocephalus Linnaeus, 1758. In Handbook of marine mammals, Vol. 4: River dolphins and the larger toothed whales, S. H. Ridgway and R. Sir Harrison (eds.). Academic Press, San Diego, California, pp. $17 \tau-233$.
SMEENK, C., AND M. J. AdDink. 1993. Sighting of a group of sperm whales Physeter macrocephalus in Dutch waters, with historical notes and the possible Orkney connection. Lutra 36: 25-29.

Trudgett, A., C. Lyons, M. J. Welsh, N. Duffy, S. J. MCCullough, AND F. MCNeilly. 1991. Analysis of a seal and a porpoise morbillivirus using monoclonal antibodies. Veterinary Record 128: 61 .

UYs, C. J., AND P. B. BEsT. 1966. Pathology of lesions observed in whales flensed at Saldanha Bay, South Africa. Journal of Comparative Pathology 76: $407-412$

Walsh, M. T., D. K. Odell, G. Young, E. D. AsPER, AND G. BOSSART. 1990. Mass strandings of cetaceans. In Handbook of marine mammal medicine: Health, disease, and rehabilitation, $L$. A. Dierauf (ed.). CRC Press, Boca Raton, Florida, pp. 673-683.

WILCOCK, B. P. 1993. The eye and ear. In Pathology of domestic animals, Vol. 1, K. V. F. Jubb, P. C. Kennedy, and N. Palmer (eds.). Academic Press, San Diego, California, pp. 441-529.

YAGER, J. A., AND D. W. SCOTT. 1993. The skin and appendages. In Pathology of domestic animals. Vol. 1, K. V. F. Jubb, P. C. Kennedy, and N. Palmer (eds.). Academic Press, San Diego, California, pp. 579-592.

Received for publication 2 December 1996 